\title{
Access to Land Influencing the Urban Development of Egypt
}

\author{
* Dr. MOHAMED RASLAN 1 (D), Dr. HANY AYYAD 2 \\ $1 \& 2$ Architecture Department, Faculty of Engineering, Alexandria University, Alexandria, Egypt \\ E mail: m.ramadan@alexu.edu.eg Email: hany.m.ayyad@alexu.edu.eg
}

\begin{tabular}{l}
\hline A R T I C L E I N F O: \\
\hline Article history: \\
Received 08 February 2018 \\
Accepted 08 May 2018 \\
Available online 15 June 2018 \\
\hline Keywords: \\
Access to land; \\
Urban development; \\
Urban growth patterns. \\
\end{tabular}

This work is licensed under a Creative Commons Attribution NonCommercial - NoDerivs 4.0. "CC-BY-NC-ND"

\begin{abstract}
A B S T R A C T
The paper seeks to assess the impact of access to land of Egypt on urban development in an attempt to identify policies and laws that can be categorized as a catalyst in urban conflict.

Systematic review of Data on land tenure environment of Egypt, land access, land governance and tenure security, the actors involved in these processes, their roles, the land tenure related challenges they face and measures that can be taken to address these challenges was collected at country level.

In the context of Egypt, Access to land is deemed with obstacles confronting beneficiaries and legal procedures that uncover dispute. By investigating the land tenure environment, conclusions could be drawn on how to improve the systems so that they can be used as development tools that decrease the probability of conflict to happen. Furthermore, by understanding how access to land plays a crucial role in urban development patterns, we can allocate recommendations for more sustainable developments.
\end{abstract}

JOURNAL OF CONTEMPORARY URBAN AFFAIRS (2019), 3(1), 82-91. https://doi.org/10.25034/ijcua.2018.4685

WwW.ijcua.com

Copyright (c) 2018 Journal Of Contemporary Urban Affairs. All rights reserved.

\section{Introduction}

Research done on urban developments in Egypt shows there is a link between land tenure and physical and spatial characteristics of developments. The UN-Habitat (2007) in their research on the condition of informal settlements in Egypt identified land tenure systems as one of the factors contributing to informal settlements in the country. The report highlighted unclear tenure relations where multiple interests on one piece of land held by different people as a major limitation to development control and direct cause for urban conflict.

Johannsen (2008) investigated informal mechanisms of accessing land in informal settlements in Cairo. His study focused on behavior patterns of key actors involved in land access from obtaining information on plot availability, setting of parcel boundaries to registration of rights. Findings of this research showed that informal processes of accessing land in Cairo are not disordered but are regulated by informal rules which draw from existing legal policies and customary rules. Yet, these policies are the main reason for conflict around multiple areas in Cairo causing the city to be contested.

\footnotetext{
*Corresponding Author:

Architecture Department, Faculty of Engineering, Alexandria University, Alexandria, Egypt

E-mail address: m.ramadan@alexu.edu.eg
} 
Although previous research on land tenure and urban developments in Egypt discussed above highlight uncertainty over existing tenure relations as a burden for land use planning, they do not illustrate how this has led to urban conflicts which leads a city to be contested. This research by examining land tenure environment processes under different land tenure systems clarifies the roles, interests, strategies and interactions of actors in these processes providing insight on the stage of the land development process in which informality occurs. The output of this research would be useful to (a) Institutions responsible for land management in Egypt (b) bodies charged with management of urban developments in Egypt (c) Civil Society Organizations undertaking various interventions on informal urban developments in Egypt (d) Institutions charged with land conflict resolution measures

\section{Methodology}

Qualitative methods was applied in collecting the data needed to adequately address the research questions. Although quantitative methods were relevant, they weren't applied due to the lack of resources and security permissions.

Data relevant to the access to land was collected mainly through literature review. Review of relevant literature also aided in the identification of bodies involved in land tenure environment processes under the land tenure systems in Egypt from which information significant to this study was pursued through expert interviews.

Responses obtained from expert interviews were transcribed and the questions as set in the interview guide and the additional questions that came up during interviews matched with the responses given.

\section{Tenure types in Egypt}

Five main types of formal land tenure exist in Egypt:

Private ownership (freehold)

Freehold land is land registered with the local district office of the Real Estate Registry Division and owned by private persons or companies. The great majority of agricultural land is privately owned, especially in the older, settled rural areas. All land not registered to private entities is technically considered to be publicly owned, although informal tenure of unregistered land in some areas is in fact considered to be quite secure. There are several restrictions on agricultural landholdings. Law No. 50 of 1969 provides that an individual cannot own more than 50 feddans of agricultural land (or its equivalent in uncultivated and desert lands) and that a family cannot own more than 100 feddans of agricultural land. The law prohibits construction of any buildings on farmland without a license from the Ministry of Agriculture and Land Reclamation.

\section{Public ownership}

Land registered as state property and not leased to a private entity is publicly owned. Land under public ownership falls into two categories: state domain, which includes desert or unclaimed lands and is administered by the governorate; and public domain, which serves a public utility such as rivers, roads, military installations, land for antiquity sites, and land set aside for development.

\section{Publicly leased land}

Land owned by the state can be leased on a long-term basis to its occupants. These leases apply in a number of circumstances, most importantly for land in reclaimed areas and for squatters (by way of a request to the governorate). In reclaimed areas, lease rates are limited (e.g., at the cost of irrigation or at $6 \%$ of the total land value) and rights may convert to ownership rights after a particular period of time.

\section{Endowment or Al-Awqaf land}

Endowment land is land set aside by the state for charitable or religious intention and usually administered by a specific ministry for it (AlAwqaf,2005). The purpose for categorizing land as Waqf is to avoid subdivision and to eliminate conflict among descendants. The revenues from the land belong to the beneficiary; Wagf land cannot be sold or mortgaged.

\section{Encroachment (Wadaa Al-Yad).}

The Civil Code makes it possible for the user or holder of a plot of land to acquire ownership of that land if it is occupied constantly for 15 years without the owner claiming his rights (Hasan, A. ,2012).

\section{Access to land}

\subsection{Introduction}

The lack of systematic land registration has become an increasing problem in Egypt. Approximately one hundred people are killed annually in Egypt due to land conflicts (Mahrus, 2009). The problem has been on the increase 
because of the fast growing population in Egypt. There are more than 93 million Egyptians in Egypt today and this number is expected to reach 100 million by 2025 (World Bank, 2016). This growth has necessitated the development of unused land. As these extensions, especially in villages or rural areas, were not implemented according to a plan followed by the state they depended on society and individuals to arrange them amongst themselves. Therefore, clashes due to a conflict of interests have been increasing and have become hard to control. Furthermore, the population growth (Egypt has a population growth of 2.51 percent per year (World Bank, 2016) creates additional problems because of the limited cultivatable land in the country. More and more people, both poorer people forced to move to the border of the old inhabited land because of the limited land available for housing in the old areas, and investors and spectators who have seen this development as a way to make money, have felt compelled to move from registered old land to the non-registered newly reclaimed desert areas.

This has meant an increase in the number of disputes about desert land that is reclaimed or that people want to reclaim. In this section we will look at the laws and regulations concerning landownership in Egypt. Afterwards, we will focus on legalizing of land channels and procedures that beneficiaries follow. Finally, the history of encroachment will be investigated while exploring all the factors that support this phenomena. Through an understanding of those factors we will be able to discuss the different elements of the phenomena of land disputes and analyse how disputes and conflicts might be prevented in the future.

\subsection{Explanation for the lack of land registration in Egypt}

Land registration is a relatively recent phenomenon in Egypt. Before the 1952 Revolution, only $6 \%$ of the population owned 65 $\%$ of the land. Afterwards, the land was redistributed and small farmers started to own some feddans. The average number of feddans owned by small farmers was one to three (Johannsen, 2008).Nowadays, still only 25 percent of cultivated land is registered. There have been efforts by the state to register the rest of the land but those measures have not corresponded with the population growth and extensions of the villages (Abdel-Qadder, 2009). Registration fees for landownership in Egypt have always been very costly, compared with most people's resources, in spite of the government's efforts to reduce costs. This is one of the main reasons why people avoid registration (Johannsen, 2008). The fees have therefore also been one of the main reasons for land violations as individuals have often been satisfied with just keeping customary contracts. This has allowed criminals to create forged Customary contracts and to attempt to prove the validity of these contracts at court and thus be able to register them.

Even foreign investors tend not to register their real estates. One example is that of Saudi investors, who own more than 100.000 properties but have not registered their property in Egypt. According to the Centre of Information of the Egyptian cabinet, only 27 percent of the real estate that the Saudi investors own, is registered (Hamilton, 2012). In 2004, the Egyptian parliament approved a bill to reduce the fees of ownership registration by one third. In this concern, the fees paid for the registration are 3 percent instead of 4.5 percent of the price of the registered land. The reason for this reduction was to get the remaining real estate that is estimated to be worth 32 billion dollars, registered. Nevertheless, in 2006 Law no. 83 was issued to modify the Real Estate Registry fees at a fixed price instead of a percentage in order to encourage investment and development in Egypt.

The objective of this law is to stop the customary contracts that have increased ownership disputes and violent conflicts in Egypt dramatically. But customary contracts are still widely used among citizens as the owners of unregistered contracts, when necessary, can prove ownership of their real estate in two lawsuits:

First: By proving the validity of the signature of their preliminary contract.

Second: By proving the validity of the whole contract. Thereafter, they can register their real estate in the Real Estate Registry Department .The state is unwilling to force citizens to register their land; instead the law tolerates the holders of unregistered contracts and gives them the chance to register their contracts in case they need to. Thus it seems that the authorities, so far, have not implemented one way standards, but instead proceed with laws and rules contradicting each other. Instead of encouraging people to prove ownership in court and thereby to register the land involved in disputes the law allows people to use unregistered land which easily can become subject to conflict.

Other reasons for the lack of land registration are due to the maze of bureaucratic 
procedures a person has to go through if he wants to own his land officially. In order to officially own a piece of land in the newly reclaimed areas in Egypt one has to go through 24 procedures, in 13 different offices, involving three different ministries (Abdelhamid, 2016). A procedure which, on average, takes between six and 11 years. Further, the formulation of urban and rural areas is unclear in the law, which has led to some problems in the areas close to the desert. Law no. 3 of 1982 illustrates the lack of formulation in the law by giving only a blurred definition of urban areas. This has led to brokers escaping both rising prices in the cities and laws directed toward the cities' urban areas by moving to the rural areas. There is a general lack of cooperation between the different authorities dealing with the issue which opens up the possibility of conflict and violations of laws as well. Experts have pointed out that there is a big problem concerning under staffing, lack of facilities and equipment (available maps are often outdated) in the authorities involved with landownership (Ismail, Head of Legal department - The Egyptian Survey Authority, 2016). Each governorate in Egypt experiences an average of 9000 land violations every year. At the same time, the average number of employees in a governorate dealing with this issue is 50 people (El-Hefnawi, 2005). This fact shows how difficult it is for authorities to handle the large number of violations. The employees' salary is very low and this makes it even harder to keep experienced officials or keep out corruption or attract a new work force.

All land in Egypt is in theory reserved for the military. To gain land ownership you need to obtain permission from the military to use the land. After getting permission from the military you can move on to getting permission from the other ministries involved. The ministries involved in land registration in Egypt are the Ministry of Agriculture and Land Reclamation, the Ministry of Housing, Utilities and Urban Communities, the Ministry of Justice, the Supreme Council of Antiquities (SCA) and the Ministry of Petroleum (Johannsen, 2008). A person needs the approval of all these authorities to officially own land. Still the military, even in case of proved ownership, has the right, at any time, to reclaim the land they consider necessary for military purposes (Sims, 2010).

In addition to the ministries involved in land registration there are local authorities in the governorates that play a role. It is the governor's responsibility to implement laws and ministerial decrees. However this also means that there are differences in coping with land ownership from governorate to governorate, though no customary contracts and encroachment are legally used in the very deep desert area, Sinai or the desert of the Red Sea area. This coincides with article 10, law no. 143, 1981 which considers Encroachment a violation of state property (Mahrus, 2009).

There are though differences in this matter from governorate to governorate. This can be seen in the case of the governorate of Marsa Matrouh where Encroachment is not illegal. There Encroachment is registered through the extradition of documents with the governor's seal and considered a step toward official ownership. This is possible in Marsa Matrouh because of Presidential Decree no. 632, article one, 1982,22 which states that certain areas and governorates, Marsa Matrouh being one of them, do not have to apply law no. 143, 1981, but can apply their own laws concerning land ownership as dictated by the governor of the area (Johannsen, 2008).

\subsection{Land Legal Access Systems}

There are different procedures and challenges to acquire legality for each land tenure form in Egypt. These procedures and challenges are different if the applicant deals with land legal obtainment or property legal obtainment. The upcoming part will be focusing on legal land obtainment.

\subsubsection{Legal Access Process of Private Land and State Private Land}

As David Sims stated, since 1946 (Law no. 114), all sales, purchases, and transfers of land must be registered with the Real Estate Registry to ensure complete legal protection for the owner, to recognize the property and allow property tax payments (Séjourné, 2012). Real Estate Registry is under the Ministry of Justice and an office exists in every governorate (Egyptian Ministry of Justice, 2008).

Acquiring land or transferring it in Egypt is not an easy or simple procedure. On the contrary it is a very long and complicated process. To acquire a property legally there are many procedures that should be followed. Acquiring private property is the easiest among all forms of property. While acquiring state Public Domain is completely forbidden and any kind of squatting on it cannot be registered by the governmental authorities. The state Private Domain can be legalized in case of squatting but with very difficult and strict procedures. The property is subdivided into built property or not built property . 


\subsubsection{Legalizing of land transmission "Non Built Property"}

The procedure is really complicated and time consuming. The owner of the property should prepare a file including application form, a primary contract and receipt of property tax "Cashf Al-Moshtamalat to the Real Estate Registry (see Error! Reference source not found.). Afterwards, the Real Estate Registry investigates the file and send it to the survey authority -Hayaat Al-Mesaha هيئة المســـاحـ that send a personnel for a field visit to check the exact location of the property, the boundaries and the total surface area and if there is an existing conflict about the land or its boundaries (Ismail, Head of Legal department - The Egyptian Survey Authority, 2016).In the field visit, if the survey authority delegate finds any conflict about the land boundaries, the legalizing process is cancelled until the conflict is resolved. This condition is itself a conflict generating policy, since whoever wants to stop the process of legalizing the ownership may create a dispute while the field visit is happening. In addition, the survey authority cannot resolve the conflict, since the maps they refer to is outdated paper based maps. Yet, up until now, no survey authority department in Egypt has a complete computerized maps for the territory it manages, including detailed parcel sizes with their owners (Ismail, Head of Legal department - The Egyptian Survey Authority, 2016).

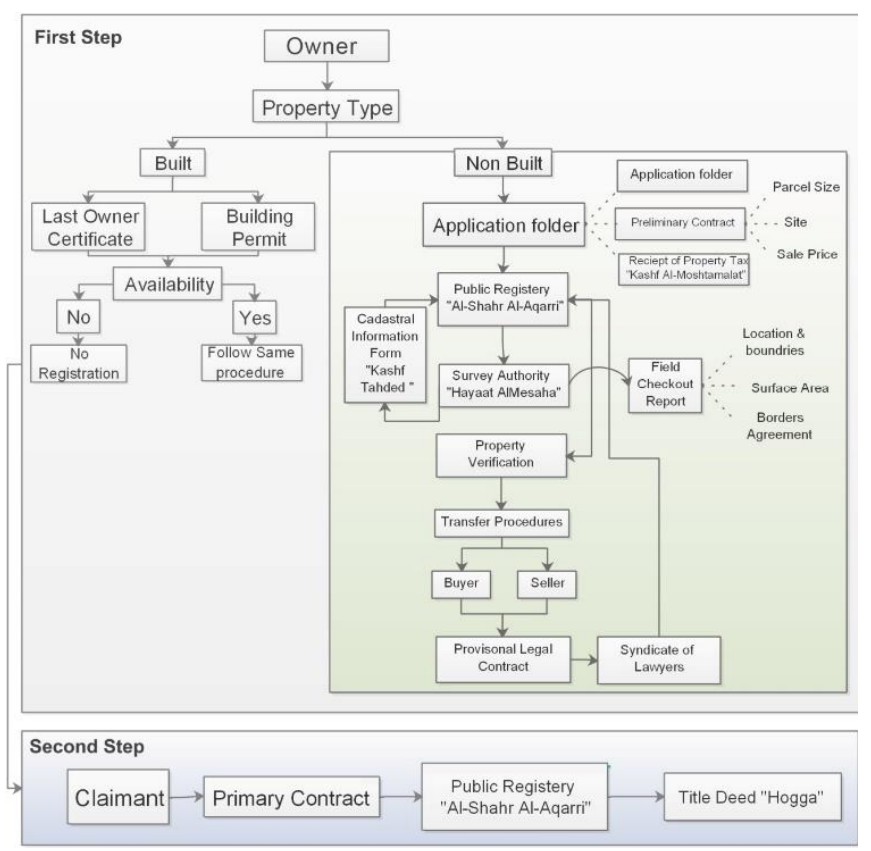

Figure 1: Legalizing of Land Transfer Property - Source: Researcher
If the field visit occurred without any dispute or conflict around the land. The survey authority send a report "Kashf Tahded كثـــ تحديد" to the Real Estate Registry with all the details of the field visit. The Real Estate Registry after checking the report and the legal aspects of the application, verifies the property to the owner. The Real Estate Registry provides the owner with a temporary legal contract that should be signed from both the seller and the buyer to complete the transfer.

This contract is first approved by the syndicate of lawyers and afterwards, sent to the Real Estate Registry for final approval. Not only that, but also a second step should be made afterwards, where the new owner (applicant for ownership) takes the primary contract to register it in the Real Estate Registry which in return provides the applicant with a title deed for the property, while the original contract remains in the Real Estate Registry in a specific department "Dar Al-Mahfozat دار الــــفوظـات " (Abdelhamid, 2016). This procedure is really inhospitable, very complicated and time consuming.

\subsubsection{Legalizing of land transfer "Built Property"}

To register a built property, the applicant for ownership should ensure two main things: (a) the seller should be registered as the last owner of the land in the Real Estate Registry and (b) the building is in the construction permitted building zone. If the two conditions are met the applicant for ownership follow the same procedures as the preceding case. While if not met, the property can never be registered. In the case of private property, the buyer and the seller must sign a primary contract "Aqd Ebtdaai - عقد إبتـائى", while signatures observed by two witnesses. The primary contract contains land's details, for example: parcel size, parcel location and sale price. For the contract to be considered officially legal, it should be registered in the Real Estate Registry (Abdelhamid, 2016) see figure 2. If the property is a state Private Domain, it gets more complicated and hard as the seller in this case is the state and it takes a lot of time to finish this transfer, according to the Egyptian Center for Economic studies, this procedure can last for 435 waiting days and costs nearly 20,000 L.E (Alfiky, 2014). 


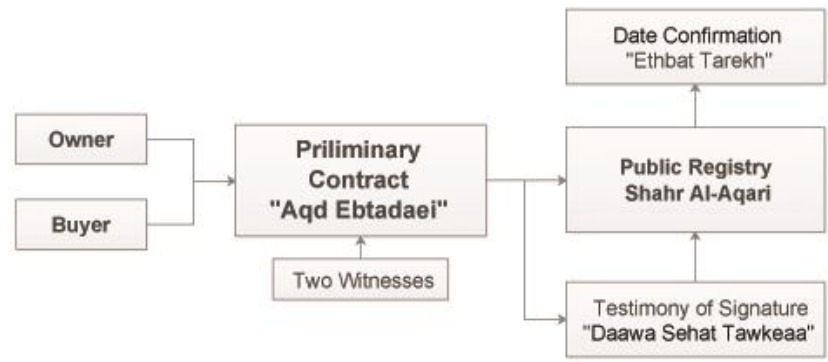

Figure 2: Legalizing of Private Property, Source: Researcher

\subsubsection{Formalization of Sales Contract}

There are two tricks that squatters use to get tenure security. The first is testimony of signature "Daawa Sehat Tawkeaa دعوة صـحــة توقيع In In this case, both the buyer and the seller sign a contract. Afterwards, the seller appears before the court; requiring confirmation for his signature. The judge gives him a testimony after verifying his signature, without giving attention to the terms of the contract. The second trick is validation of purchase date"Ethbat Tarekh إثبات "تاريخ" (see Figure 3). In this case, the buyer after signing the contract, approaches the local Real Estate Registry to confirm the date of sale. According to an interview conducted by the author with a lawyer (Al-Gammal, 2016), these papers are not title deeds and do not secure tenure. Yet, they can be used afterwards in the court along with other documents to strengthen the applicant for ownership situation in the court to achieve tenure security and prevent forced eviction.

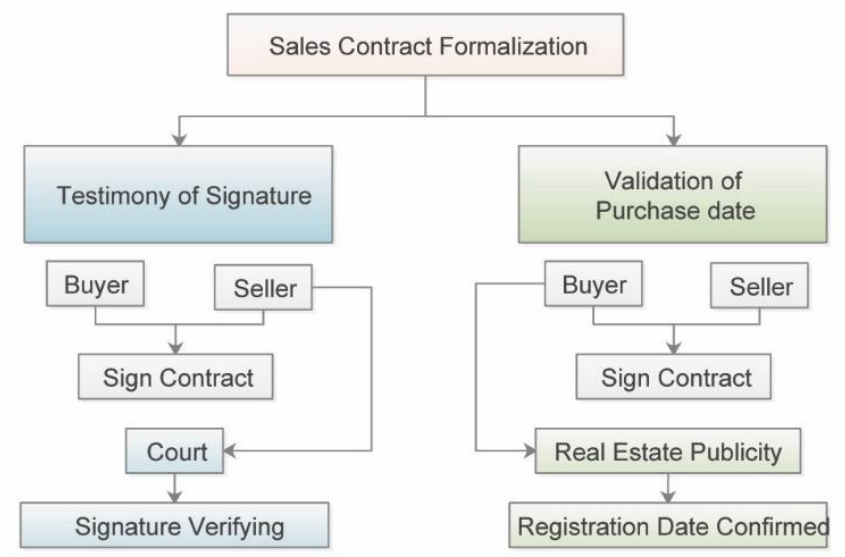

Figure 3: Formalization of Sales Contract - Source: Researcher

\subsection{Supposition}

There is insufficient law enforcement in Egypt. The Egyptian authorities have for decades tried to implement legal land registration without much success. Most of the conflicts and the violations over land are due to the lack of implementation and monitoring of laws. Although the state has criminalized encroachment in most places in Egypt, the practice continues and even increased after implementation of Law no. 134, 2006, which prohibited any further acquirement of land through encroachment after August 2006 (Abdelhamid, 2016). The continuing increase of the practice was partly due to people trying to gain as much land as possible before the activation of the law.

Law no. 143, 1981 was clear about considering encroachment a crime in large parts of Egypt. However, so far the state has not intervened to stop the violators. Furthermore, the state has not protected official landowners, as an individual can buy land legally and be forced to pay a second time because of tribes who claim land ownership through encroachment (Al-Gammal, 2016).The state's reduction of registration fees has not encouraged people to register their land. The law gives the right to holders of customary contracts to have legal possession of their land, although not through full ownership. As long as customary contracts are partly legal, there is little chance that people will start to register their land.

\section{Impact on Urban Development patterns}

According to (Guadiano, 2005) There are five types of urban growth patterns which can be represented in fractal cells (see figure 4:) :

1-Type 1: Small and isolated build up patches

2-Type 2: Dispersed built up patches

3- Type 3: Metastatic growth

4-Type 4: Rapid growth and metastatic consolidation

5-Type 5: Consolidated compact areas 


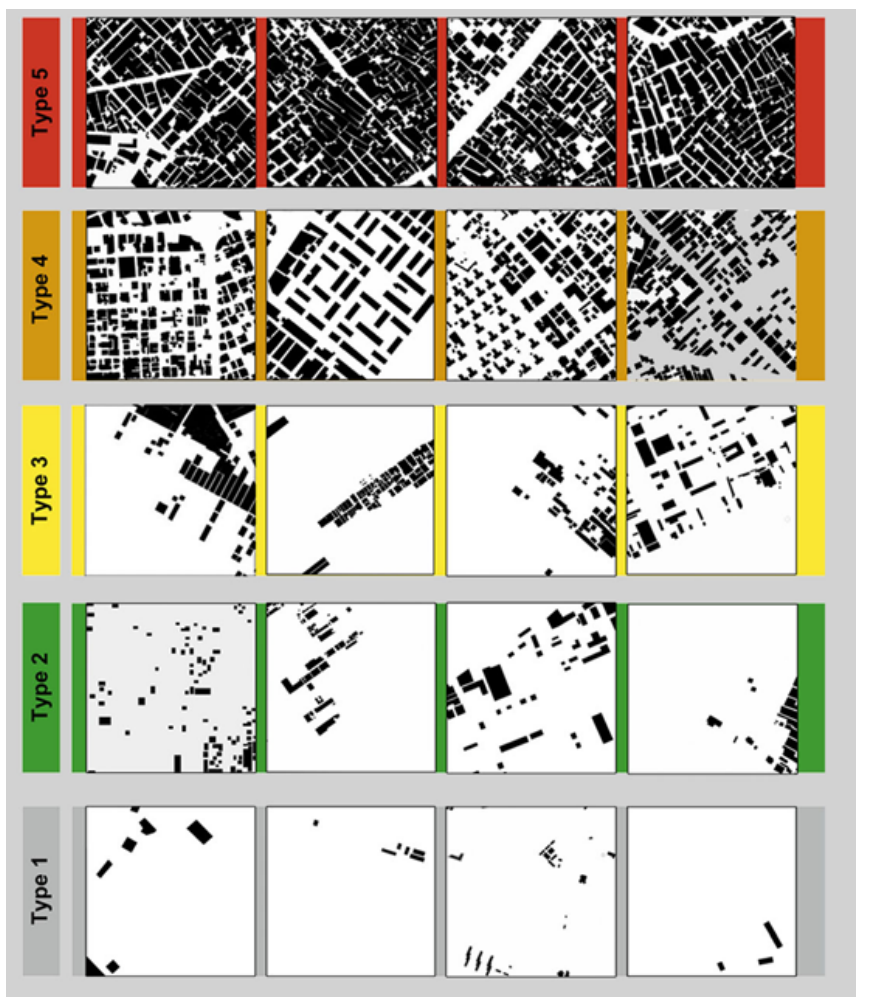

Figure 4: Types of Urban Growth Patterns - Source: Gaudiano 2005

By referring to the fractal analysis of the Eastern part of Metropolitan Alexandria of years 1959, 1985 and 2014 applied by (Hasan, 2012), shows five different types of urban growth patterns: Ranging from the cells that have high fractal dimensions (type 4 and 5), representing the most compact, homogenous patterns and uniform distribution of built-up masses, and found generally in the middle and eastern districts; to the cells that have lower fractal dimensions (types 2 and 3), representing non uniform distribution of urban patterns and contrasting lacuna sizes as represented in the emerging peri-urban informal expansions.
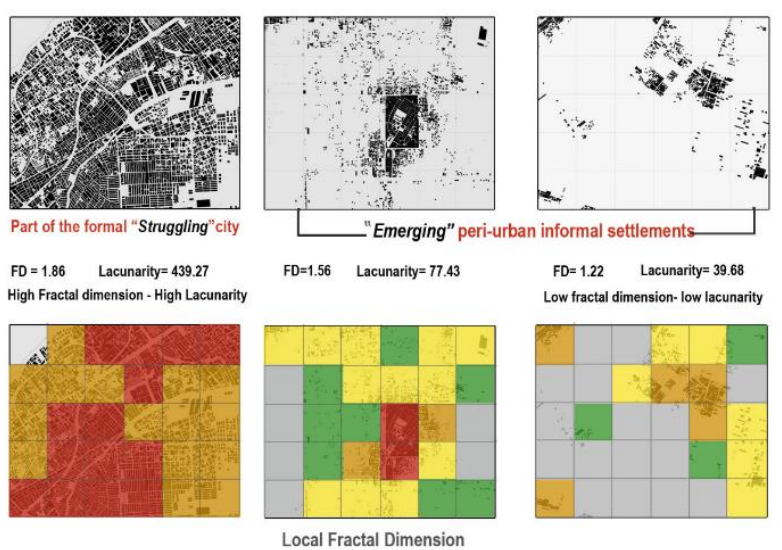

Figure 5: Examples of Fractal cells representing different growth types in Alexandria - Source: Hasan,2012
According to Hasan (2012), results from the historical data analysis reveal that the development of urban areas in Alexandria generally starts by type 1 and then evolves to higher types that are more compact. It is observed also that the types 1,2 and 3 dominate dispersed areas (at the city peripheries)(See Figure 5). In contrary, the built-up areas in the city core and extensions are dominated by cells of type 4 and 5 . It is observed that the Central Business District (CBD) exhibits a uniform saturated distribution of high fractal dimension (mainly types 4 \& 5) that did not change throughout the study timeline.

\subsection{Impact of Land Tenure Policies on Urban Growth Patterns}

In the upcoming section we will investigate one case of change from one type of urban pattern to another. By focusing the study on the role of access to land policies play as a catalyst in changing urban growth patterns. The case of $\mathrm{Al}$ Maamoura zone will focus on the change from type 2 (Dispersed built up areas) to type 3 (Metastatic growth).In the case study we will investigate the characteristics of the focus zone, the accessed land tenure form, how tenure security is acquired and the urban growth pattern across time.

\subsection{Case Study: Al-Maamoura}

Al-Maamoura zone is located in Al-Montazah Second District in the eastern part of Alexandria. The zone is composed of roughly $60 \%$ agricultural land while the rest is considered informal peripheral urban settlements apart from the gated community of Al-Maamoura Coastal apartments see figure (Ismail, Head of legal department, Egyptian Survey Authority, 2017).The zone is connected with the rest of the city through two main roads, Mostafa Kamel and Malek Hefni.

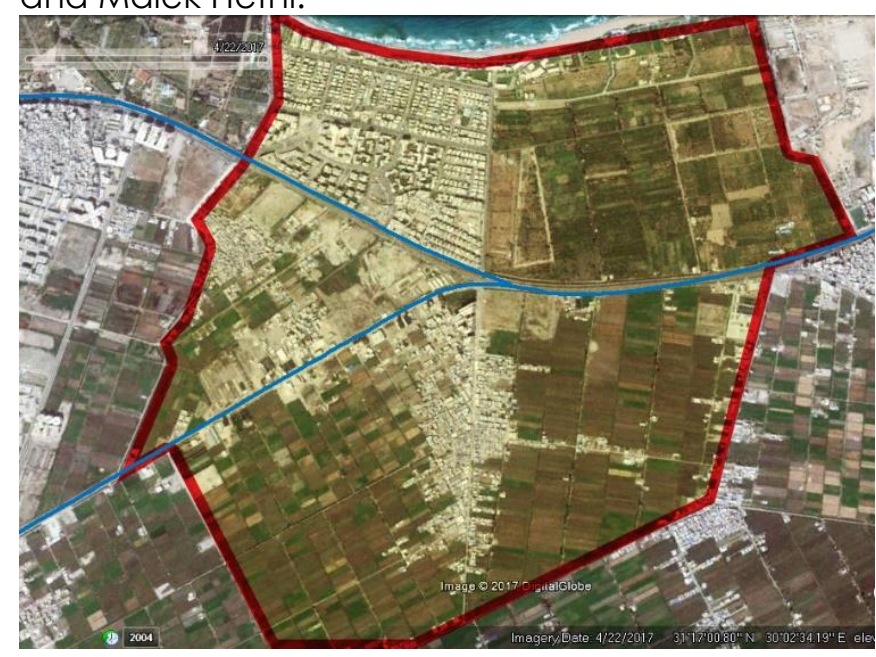

Figure 6: Focus Zone in Al-Maamoura - Source: Google Earth 

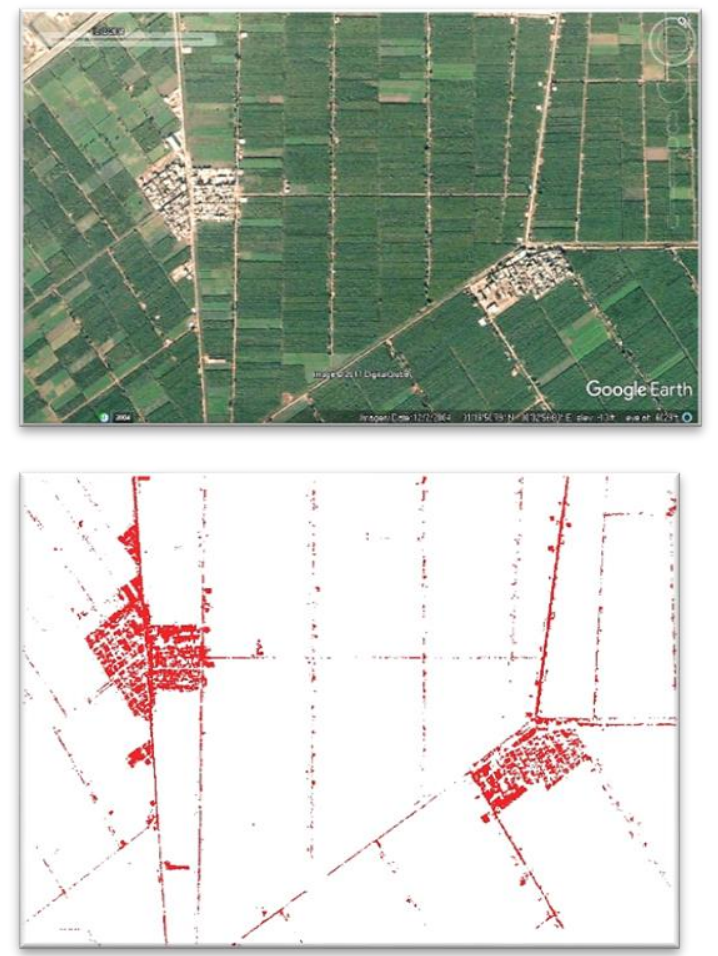

Figure 7: Scattered Built up areas in Al-Maamoura - Source: Google Earth

In 2004, urban growth pattern in Al-Maamoura could be categorized as scattered built up areas, where families working on the agricultural land gathered in groups of small rural houses see figure 7. These houses where registered and organized through the governorate with supply of fundamental amenities like electricity and sewage.

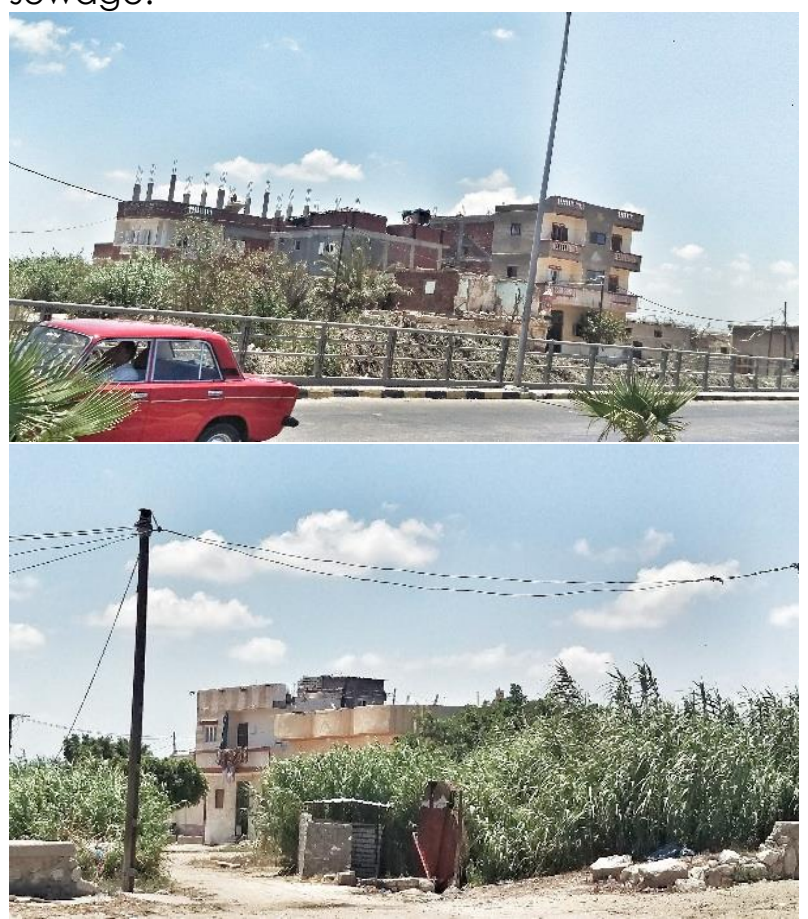

Figure 8: Urban sprawl on Agricultural land in Al-Maamoura - Source: Researcher
Due to the system of land subdivision mentioned earlier, one piece of land could be subdivided into small plots as a result of the inheritance system. Consequently generation after generation the land becomes smaller, and nowadays the characteristic width of many plots is 7.29 meters. Most of the cases, owners of these plots have two options, either sell or rent this plot cheaply for the adjacent owner to add it with the same crops he cultivate, or build a house to live in or sell it for a much higher price. While the later is the more feasible option for the owner, it is the main reason of the long term of urban sprawl on agricultural land (see figure 8).

Starting from 2016, the urban growth pattern had changed to be metastatic growth where built up areas are becoming more densified and starting to outreach to surrounding areas. It's anticipated with that range of growth to reach type 4 of urban growth patterns within 5 years. While by 2030 most of the agricultural land of AlMaamoura will be malformed into informal settlements unless the authorities took serious measures (see figure 9).
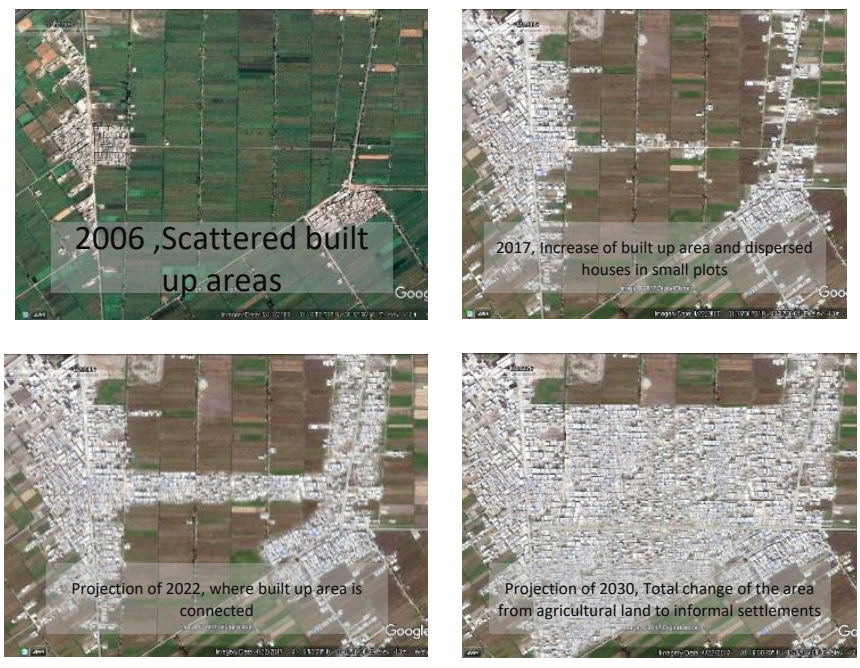

Figure 9: Development and Projection of informal settlement growth in Al-Maamoura - Source: Researcher

Since legalizing of non-built property transfer is a very difficult and time consuming procedure as mentioned earlier, Most of the owners tend to go with legalization of sales contract in any property transfer. Through Testimony of Signature which is acquired from court and Validity of purchase Date acquired from Real Estate Publicity, the owner and the buyer affirm 
their purchase. Although, these papers are not title deeds and do not secure tenure. Yet, they can be used afterwards in the court along with other documents to strengthen the applicant for ownership situation in the court to achieve tenure security and prevent forced eviction.

Another vital aspect in this case, is that the type of tenure has greatly affected how holders of the land dealt with their agricultural land. In figure 10, the red shaded area are under tenure type of publicly leased land, yet the blue shaded areas are free-hold land. It's wellconceived that the publicly leased land plots have no violations however holders of the free hold have altered and subdivided their land informally and their abuses couldn't be monitored easily.

While building on agricultural land is criminalized, still there are law loopholes that the owners use to get away with this act. When an official from the district files a violation case on agricultural land, the court requires a testimony to affirm the violation. The testimony could be acquired from an agricultural engineer, which can easily be bribed from the owners or, from a neighbor of the agricultural land in question who mostly has his own violation or might falsify his testimony for his neighbor (the violator owner).According to Al-Gammal (2016), this could easily be avoided if the court acquired its testimony from the official who filed the violation or his head.

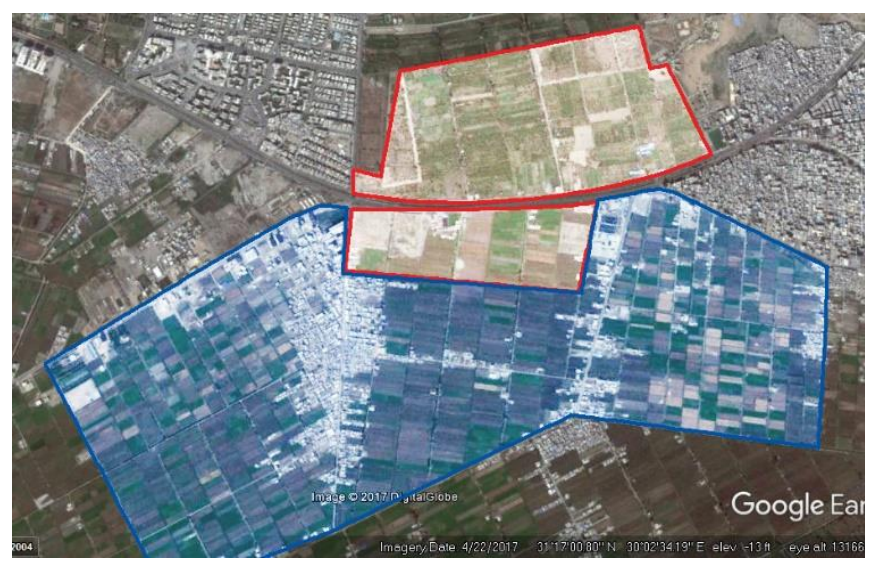

Figure 10: Areas of different land tenure form in AlMaamoura - Source: Researcher based on Google Earth

\section{Conclusion}

The objective of this study was to investigate the role of the access to land conflict situations and its impact on urban development patterns. It explained how although the structures for land tenure development programs, administrations and legal policies are in place, they can fail to act as development tools and can actually generate conflict. Access to land can be addressed in the developing environments through laws reforming efforts in which state led and community led approaches are used to increase the accessibility of land to landless individuals, as well as law enforcing regulations related to legal access. The main purpose of this research was to show that the land tenure environment can play a vital role in developing strategies for land tenure. To do so, it was crucial to explore the value of the land tenure environment in addressing the issues that often lead to conflict. The hypothesis is made that the more effective the environment, the greater its ability towards acting as a development tool. By investigating the land tenure environment, conclusions can be drawn on how to improve the systems so that they can be used as development tools that decrease the probability of conflict to happen. This paper focused on Egypt due to its history of high rate of land tenure conflict together with its dependence on land for economic growth. In many other countries, land tenure conflicts either appear in the outcome of other profound conflicts.

This study can be expanded in several ways to fully understand the relationship between the land tenure environment and land conflict, where a comparative study could be conducted between various land tenure environments in different countries and how policies were reformed in order to vanquish land conflict from its roots.

\section{Acknowledgments}

Thanks to all the interviewees that helped in collecting case relevant data. Additionally, The researcher would like to show his sincere gratitude to Prof. Hany Ayyad for his guidance throughout the research. This research did not receive any specific grant from funding agencies in the public, commercial, or not-forprofit sectors.

\section{Conflict of interests}

The author declares no conflict of interest.

\section{References}

Abdelhamid, E. (2016, May 10). A technical engineer - State Property Protection Agency. (M. Raslan, Interviewer) Alexandria.

Abdel-Qadder, M. (2009, January 9). AlBashayer magazine. The man who protects the land in Egypt. Retrieved from https://www.researchgate.net/profile/Ayman 
Othman/publication/271906673 SB13 Cairo Proceedings/links/54d5f7ee0cf246475808cb 53/SB13-Cairo-Proceedings.pdf

Alfiky, M. (2014). Community Based Security of Tenure. Stuttgart: University of Stuttgart Press, 50-89. Retrieved from http://www.academia.edu/36654940/Comm unity_Based_Security of Tenure_Initial_Frame work for Squatter_Areas in Cairo

Al-Gammal, Y. (2016, September 3). Lawyer Expert in land conflicts-. (M.Raslan, Interviewer)

Egyptian Ministry of Justice. (1984).103-142. Retrieved from http://documents.worldbank.org/curated/en 1289771468037496435/pdf/365200EGOWhite10 121041200701 PUBLIC $1 . p d f$

Egyptian Ministry of Justice. (2008). The Encyclopedia of Unified Building . Cairo. Retrieved from http://www.cpasegypt.com/pdf/Doha_Moustafa/MS.c/Egypti an\%20Urban\%20Planning\%20Institutional\%20Fr amework-Doha.pdf

El-Hefnawi, A. I. (2005). Protecting' agricultural land from urbanization or =managing' the conflict between informal urban growth while meeting the demands of the communities. Brasilia: World Bank Urban Research Symposium, 3-6. Retrieved from http://siteresources.worldbank.org/INTURBAN DEVELOPMENT/Resources/336387-

\section{$1269364699096 / 6892630-$}

$1269364758309 /$ elhefnawi.pdf

Ababsa (role)edt, M., Dupret (role)edt, B., Denis (role)edt, E., Léna, E., Ferrier, M., Séjourné, M., ... Jähnigen, F. (2012). Popular housing and urban land tenure in the Middle East: case studies from Egypt, Syria, Jordan, Lebanon, and Turkey. Cairo: American university in Cairo press. Retrieved from http://lib.ugent.be/catalog/rug01:002048185

AHMAD, B. (2012). David Sims 2011: Understanding Cairo: The Logic of a City out of Control. Cairo and New York: The American University in Cairo Press. International Journal of Urban and Regional Research, 36(6), 13571358. https://doi.org/10.1111/j.14682427.2012.01216 4.x

Hamilton, N. (2012). Land, Legitimacy and Governance in Revolutionary Cairo. New York: Columbia University Press, 20-31. Retrieved from

http://csud.ei.columbia.edu/files/2012/08/120 311-SIPA-EPD-Cairo-Land-LegitimacyGovernance.pdf

Hasan, A. (2012). Analyzing Urban Growth Patterns in Metropolitan Alexandria. Faculty of Engineering,Alexandria University Journal, 22-
29.

Retrieved

from

http://www.eulc.edu.eg/eulc v5/Libraries/Th esis/BrowseThesisPages.aspx? fn=PublicDrawT hesis\&BibID $=12297954$

Ismail, A. (2016, July 10). Head of Legal department - The Egyptian Survey Authority. (M. Raslan, Interviewer)

Ismail, A. (2017, 1 10). Head of legal department, Egyptian Survey Authority. (M. Raslan, Interviewer)

Johannsen, A. T. (2008). Landownership disputes in Egypt. Cairo: American University in Cairo Press.

https://www.arabwestreport.info/sites/default /files/pdfs/AWRpapers/paper15.pdf

Kumar, R. (2005). Research Methodology: A step by step guide for beginners. London: SAGE Publications.

http://www.sociology.kpi.ua/wpcontent/uploads/2014/06/Ranjit Kumar-

Research_Methodology_A_Step-by-

Step_G.pdf

Mahrus, M. N. (2009, Week 22). Land registration problems in Egypt. Arab-West Report. http://www.arabwestreport.info/sites/default /files/pdfs/coptic stats/copticmigration_statis tics-list of articles without excerpts.doc

Sejourne , M., Dupret (role)edt, B., Denis (role)edt, E., Léna, E., Ferrier, M., Séjourné, M., ... Jähnigen, F. (2012). Popular housing and urban land tenure in the Middle East: case studies from Egypt, Syria, Jordan, Lebanon, and Turkey. Cairo: American university in Cairo press. Retrieved from http://lib.ugent.be/catalog/rug01:002048185

Sims (2011). Understanding Cairo: The Logic of a City out of Control. Cairo and New York: The American University in Cairo Press. International Journal of Urban and Regional Research, 36(6), 1357-1358. https://doi.org/10.1111/j.1468-

2427.2012.01216 4.x

World Bank. (2016). World DataBank : World Development Indicators. http://databank.worldbank.org/data/reports. aspx? source $=2 \&$ country=EGY\#. 